\title{
Conversion of $T$ cells to $B$ cells by inactivation of polycomb-mediated epigenetic suppression of the B-lineage program
}

\author{
Tomokatsu Ikawa, ${ }^{1,2,3}$ Kyoko Masuda ${ }^{2,4}$ Takaho A. Endo ${ }^{5}$ Mitsuhiro Endo,${ }^{6}$ Kyoichi Isono ${ }^{6}{ }^{6}$ \\ Yoko Koseki, ${ }^{6}$ Rinako Nakagawa, ${ }^{7}$ Kohei Kometani, ${ }^{8}$ Junichiro Takano, ${ }^{1,6}$ Yasutoshi Agata, \\ Yoshimoto Katsura, ${ }^{2,10}$ Tomohiro Kurosaki, ${ }^{7,8}$ Miguel Vidal, ${ }^{11}$ Haruhiko Koseki, ${ }^{6}$ \\ and Hiroshi Kawamoto ${ }^{2,4}$ \\ ${ }^{1}$ Laboratory for Immune Regeneration, RIKEN Center for Integrative Medical Sciences, Yokohama 230-0045, Japan; ${ }^{2}$ Laboratory \\ for Lymphocyte Development, RIKEN Research Center for Allergy and Immunology, Yokohama 230-0045, Japan; ${ }^{3}$ PRESTO \\ (Precursory Research for Embryonic Science and Technology), Japan Science and Technology Agency, Saitama 332-0012, Japan; \\ ${ }^{4}$ Department of Immunology, Institute for Frontier Medical Sciences, Kyoto University, Kyoto 606-8507, Japan; ${ }^{5}$ Laboratory \\ for Integrative Genomics, RIKEN Center for Integrative Medical Sciences, Yokohama 230-0045, Japan; ${ }^{6}$ Laboratory \\ for Developmental Genetics, RIKEN Center for Integrative Medical Sciences, Yokohama 230-0045, Japan; ${ }^{7}$ Laboratory for \\ Lymphocyte Differentiation, Immunology Frontier Research Center, Osaka University, Suita 565-0871, Japan; ${ }^{8}$ Laboratory \\ for Lymphocyte Differentiation, RIKEN Center for Integrative Medical Sciences, Yokohama 230-0045, Japan; ${ }^{9}$ Department \\ of Immunology and Cell Biology, Graduate School of Medicine, Kyoto University, Kyoto 606-8501, Japan; ${ }^{10}$ Division of Cell \\ Regeneration and Transplantation, Advanced Medical Research Center, Nihon University School of Medicine, Tokyo 173-8610, \\ Japan; ${ }^{11}$ Centro de Investigaciones Biologicas, Consejo Superior de Investigaciones Cientificas, 28040 Madrid, Spain
}

In general, cell fate is determined primarily by transcription factors, followed by epigenetic mechanisms fixing the status. While the importance of transcription factors controlling cell fate has been well characterized, epigenetic regulation of cell fate maintenance remains to be elucidated. Here we provide an obvious fate conversion case, in which the inactivation of polycomb-medicated epigenetic regulation results in conversion of $T$-lineage progenitors to the B-cell fate. In T-cell-specific Ring1 A/B-deficient mice, T-cell development was severely blocked at an immature stage. We found that these developmentally arrested T-cell precursors gave rise to functional B cells upon transfer to immunodeficient mice. We further demonstrated that the arrest was almost completely canceled by additional deletion of $\operatorname{Pax} 5$. These results indicate that the maintenance of T-cell fate critically requires epigenetic suppression of the B-lineage gene program.

[Keywords: T-cell development; epigenetics; reprogramming; B cell; lineage commitment; transcription factor]

Supplemental material is available for this article.

Received September 12, 2016; revised version accepted November 3, 2016.

The process by which progenitors with multiple developmental potentials terminate some of them is termed lineage commitment. Lineage commitment generally proceeds in two steps: First, in the specification step, progenitors are biased to produce a certain lineage but still retain their other potentials. Second, in the determination step, progenitors become determined to produce that lineage but not others (Rothenberg et al. 2008; Mandel and Grosschedl 2010; Aloia et al. 2013).

In general, during the progression to the lineage determination step, transcription factors initially determine

Corresponding authors: tomokatsu.ikawa@riken.jp, kawamoto@frontier. kyoto-u.ac.jp

Article published online ahead of print. Article and publication date are online at http://www.genesdev.org/cgi/doi/10.1101/gad.290593.116. which genes are activated or silenced, and this is followed by epigenetic mechanisms that stably maintain the activated or silenced status of the affected genes by histone modification or DNA methylation. In that sense, transcription factors primarily serve as major lineage determinants. Indeed, it is well known that cell fate can be changed by genetically modifying transcription factors. For example, deletion of PAX5 and EBF1 in early B-lineage cells leads to generation of other hematopoietic lineage

(C) 2016 Ikawa et al. This article is distributed exclusively by Cold Spring Harbor Laboratory Press for the first six months after the full-issue publication date (see http://genesdev.cshlp.org/site/misc/terms.xhtml). After six months, it is available under a Creative Commons License (Attribution-NonCommercial 4.0 International), as described at http:// creativecommons.org/licenses/by-nc/4.0/. 
cells (Nutt et al. 1999; Cobaleda et al. 2007; Nechanitzky et al. 2013), and overexpression of CEBPa leads to conversion of B- or T-lineage cells into macrophages (Xie et al. 2004; Laiosa et al. 2006). Moreover, recent studies of socalled "reprogramming" have shown that somatic cells can be converted into embryonic stem (ES)-like cells or directly into other types of somatic cells when they are provided appropriate transcription factors (Takahashi and Yamanaka 2006; Ieda et al. 2010; Szabo et al. 2010).

On the other hand, in the case of epigenetic mechanisms, alteration of the epigenetic status usually does not lead to drastic cell fate conversions. Polycomb group (PcG) proteins are some of the major players in epigenetic repression of genes (Sparmann and van Lohuizen 2006; Aloia et al. 2013). In mice deficient for a polycomb component, an impairment of anterior transformation of vertebral identity as well as a defect in the development of various types of hematopoietic cells have been reported (van der Lugt et al. 1994; Iwama et al. 2004; Cales et al. 2008; Miyazaki et al. 2008; Oguro et al. 2010). However, so far, no cases of obvious cell fate conversion have been reported in mice with genetically modified polycomb components. This is also true for other epigenetic modulators, such as DNA methyltransferase (Trowbridge et al. 2009; Challen et al. 2014) or AT-rich sequence binding 1 (Satb1) (Satoh et al. 2013; Will et al. 2013).

We focused on the process of lineage restriction from multipotent hematopoietic stem cells (HSCs) to T-cell progenitors. T cells are produced in the thymus from progenitors derived from fetal liver or bone marrow (BM). In the thymus, during the immature $\mathrm{CD} 4^{-} \mathrm{CD} 8^{-}$(doublenegative [DN]) stage, cells differentiate from the DN1 to DN4 stages, and TCR $\beta$ chain gene rearrangement takes place at the DN3 stage. DN cells then differentiate into the $\mathrm{CD}^{+} \mathrm{CD}^{+}$(double-positive [DP]) stage and then into the mature CD4-single-positive (SP) or CD8SP stage. It was shown previously that the restriction step from HSCs toward T-cell progenitors is initiated by the production of myelo-lymphoid progenitors (Lu et al. 2002) followed by the myeloid-T progenitors (Bell and Bhandoola 2008; Wada et al. 2008). We further showed that such myeloid-T progenitors become determined to the T-cell lineage at the DN2 stage (Masuda et al. 2007) and that this $\mathrm{T}$-lineage determination step is driven by the transcription factor Bcl11b (Ikawa et al. 2010; Li et al. 2010a,b). It then became of interest to ask how the T-cell-determined status is maintained.

PcG proteins consist of two main complexes, termed Polycomb-repressive complex 1 (PRC1) and PRC2. PRC2 complexes initially induce histone H3K27 trimethylation (H3K27me3), and, subsequently, RING finger E3 ligases of PRC1 complexes catalyze histone H2AK119 monoubiquitylation, leading to a conformational change of histones to a repressive state (Aloia et al. 2013). Ring1B and its paralog, Ring1A, are components of PRC1 that mediate monoubiquitilation of H2AK119. They associate with many other proteins such as Bmi-1, Mel18, and Phc1 to form the core PRC1 complexes. Previous reports have shown that deletion of $M e 118$ or Bmil results in the impaired proliferation of thymocytes at the DN2 stage or
DN3 stage, respectively (Miyazaki et al. 2005, 2008). However, the deletion of each gene does not completely abrogate PRC1 function, since these molecules have other compensatory partner molecules. It has been reported that the deletion of Ring $1 b$ led to severe gastrulation defects and embryonic lethality (Voncken et al. 2003), whereas the inactivation of Ring $1 a$ in mice resulted in no overt phenotypes, suggesting the functional predominance of Ring1B over Ring1A (del Mar Lorente et al. 2000).

In order to completely inactivate the function of PRC1 complexes, we used a Ring $1 b$ conditional deletion in the setting of a Ring1a-deficient background. We found that the T-cell development was blocked at the immature $\mathrm{CD}^{-} \mathrm{CD}^{-} \mathrm{DN}$ stage in the thymi of Ring1A/B-doubledeficient mice. This developmental block was partially rescued by the additional deletion of $C d k n 2 a$, a cell cycle inhibitor, resulting in the generation of $\mathrm{CD} 4{ }^{+} \mathrm{CD} 8^{+} \mathrm{DP}$ cells. We further showed that these DP cells were able to differentiate into functional $\operatorname{IgM}^{+}$B cells upon transfer to immunodeficient mice. On the other hand, the severe T-cell developmental block seen in Ring1a/b conditional deficient mice was almost overcome by additional deletion of Pax5, demonstrating that Pax5 is a major target of polycomb during early T-cell development. These results indicate that the maintenance of $\mathrm{T}$-cell fate requires continuous epigenetic suppression of the B-lineage-specific gene program.

\section{Results}

\section{Ring $1 a / b$ is essential for T-cell development}

To examine the expression profiles of Ring1B in the hematopoietic system, we first analyzed Ring1B-YFP reporter mice in which YFP-coding sequences were knocked into the Ring1B gene locus (Isono et al. 2013). Ring1B was expressed at a higher level in DN cells than DP, CD4SP, or CD8SP cells, peaking at the DN2 stage (Supplemental Fig. S1A-D). Additionally, the expression of Ring1B in DN cells was higher than that of mature $\mathrm{T}$ and $\mathrm{B}$ cells in the spleen or myeloid and B cells in the BM (Supplemental Fig. S1E-H).

To study the function of Ring $1 a / b$ during T-cell differentiation, we crossed Ring $1 a^{-1-}$ mice and mice with transgenic expression of Cre recombinase driven by the Lck promoter and carrying loxP-flanked alleles encoding

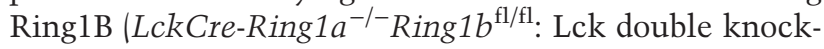
out) mice (Fig. 1A,B; Supplemental Fig. S2A). The T-cellspecific Lck-Cre gene specifically deletes the floxed Ring $1 b$ allele at the DN2-3 stage in T cells in the thymus. In Lck double-knockout mice, the number of thymocytes was reduced to $\sim 5 \%$ of that in the Ring $1 a^{-/}$Ring $1 b^{\mathrm{fl} / \mathrm{fl}}$ control mice (Fig. 1B). TCR $\beta^{+}$cells were nearly absent, and T-cell development was completely blocked at the DN3 stage in Lck double-knockout mice. While the proportion of $\mathrm{TCR} \gamma \delta^{+}$cells was increased, their absolute number did not significantly change in Lck doubleknockout mice (Supplemental Fig. S2C). This could be because most of the $\gamma \delta^{+}$T-cell precursors diverge before the DN3 stage, where the LckCre activity becomes on. 
A

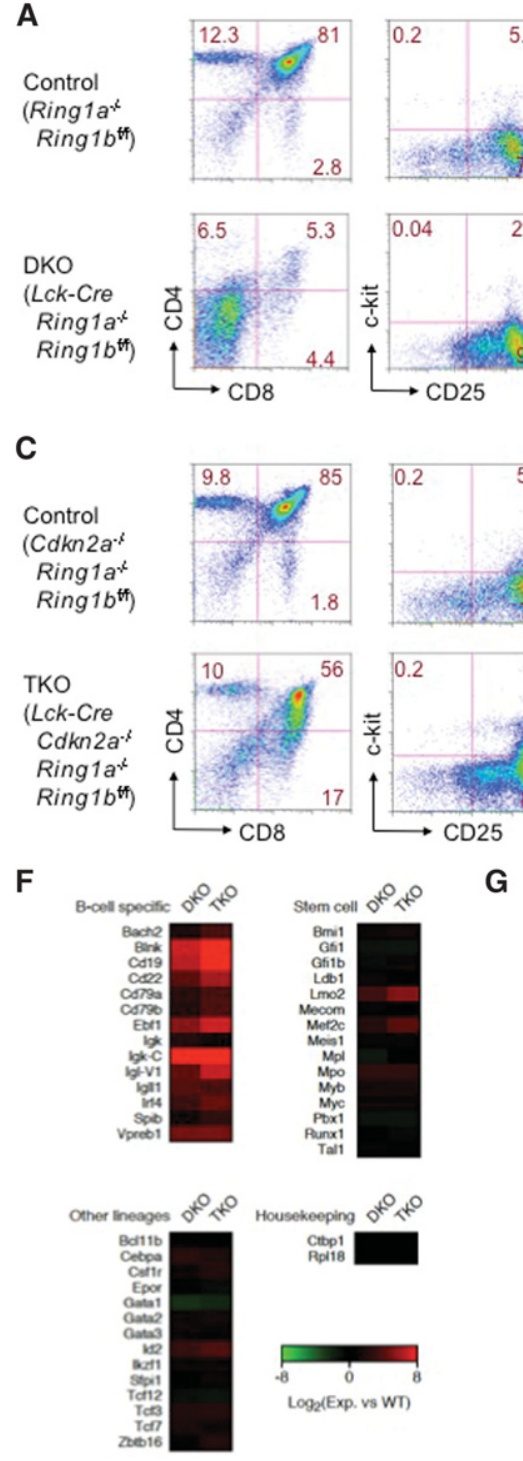

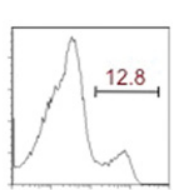

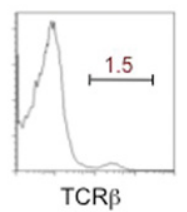

E
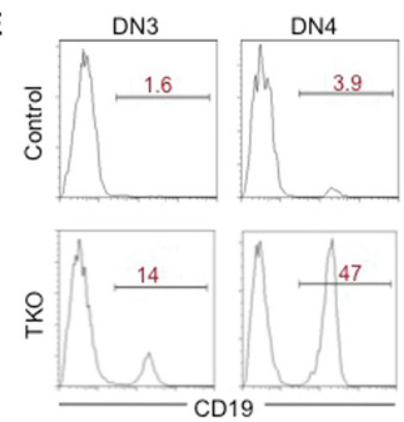

G
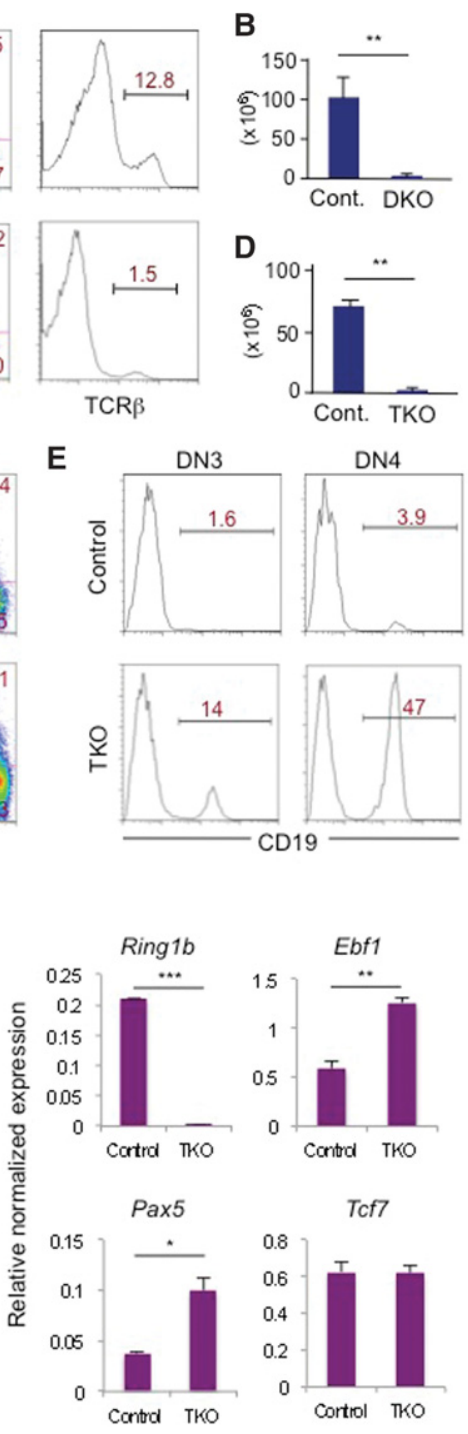

DN4

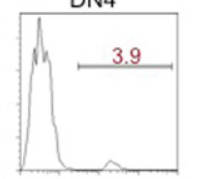

with control mice identified by microarray analysis. (G) Thymic DN3 cells from Ert2Cre(-) (control) or Ert2Crel+) (triple knockout) Cdkn2a $a^{-/-}$Ring1a $a^{-/}$ Ring $1 b^{\mathrm{t} / \mathrm{fl}}$ mice were sorted and cultured on TSt-4/ Delta-like 1 (DLL1) cells in the presence of 4-hydroxytamoxifen (4-OHT). The cultured cells were harvested at day 3, and quantitative RT-PCR (qRT-PCR) was performed for expression of the indicated genes. Data are representative of at least three independent experiments. Mean \pm SD. $\left.\left.\left(^{*}\right) P<0.05 ;{ }^{(* *}\right) P<0.01 ;{ }^{* * *}\right) P<$ 0.001 , Student's $t$-test in $B, D$, and $G$.
We also generated double-knockout mice using Cd4Cre whose Cre expression was controlled by the Cd4 promoter and found that the frequency of $\mathrm{T}$ cells in the thymus and spleen was similar to that of the control mice (Supplemental Fig. S3A,B), indicating that Ring $1 a / b$ is dispensable at later stages of T-cell development.

$C d k n 2 a$, a cyclin-dependent kinase (CDK) inhibitor, is known to be an important target of polycomb-mediated repression in hematopoietic lineages. Inactivation of Cdkn2a has been shown to restore the defective self-renewal capacity of HSCs and thymocyte proliferation observed in Bmil-defecient mice (Miyazaki et al. 2008; Oguro et al. 2010). To study the role of Cdkn2a on the Lck double-knockout phenotype, we generated Lck double-knockout mice on a Cdkn2a $a^{-/-}$background (Lck triple-knockout mice). We found that in the Lck tripleknockout mice, the number of thymocytes was not restored; however, some DP cells were generated (Fig. 1C, D; Supplemental Fig. S2B,D). Such minimal rescue in this setting may indicate the existence of other essential target genes whose derepression hampers T-cell development. We then noticed that CD19 is expressed by DN3 and DN4 cells in the Lck triple-knockout mice (Fig. 1E). Global gene expression profiles of Lineage marker-negative $\left(\operatorname{Lin}^{-}\right)$cells in the thymus revealed that several B-cell lineage-specific genes but not other lineage markers or stem cell-related genes were substantially up-regulated in the Lck double-knockout and Lck triple-knockout T-cell progenitors (Fig. 1F). To further characterize the DN3 and DN4 cells in the thymi of Lck double-knockout mice, expression of B-lineage-associated genes was analyzed by quantitative RT-PCR (qRT-PCR). Expression of Ebf1 and Pax5 in DN3 cells of Lck double-knockout mice was substantially up-regulated, although the level was still low compared with that of $\mathrm{CD} 19^{+}$cells in normal BM (Supplemental Fig. S4A,C). Of note, the expression of Ebf1, Pax5, Cd79a, Cd79b, and Vpreb1 was increased dramatically in DN4 cells in Lck double-knockout mice, 
indicating that the derepression of B-lineage-associated genes started at the DN3 stage but became prominent at the DN4 stage (Supplemental Fig. S4B,C). This is consistent with a previous report that showed the premature derepression of B-lineage genes in HSCs from Bmil-deficient mice (Oguro et al. 2010).

To confirm that derepression of B-lineage genes really occurs at the DN3 stage, we generated triple-knockout mice with an Ert2-Cre transgene encoding a hormone-inducible Cre-estrogen receptor fusion protein (Ert2CreCdkn2 $a^{-/-}$Ring $1 a^{-/-}$Ring $1 b^{\text {fl/fl }}$ [ERT2 triple-knockout] mice), in which triple-knockout status can be induced by exposure to 4-hydroxytamoxifen (4-OHT). DN3 cells from ERT2 triple-knockout mice were cultured on TSt4/Delta-like 1 (DLL1) cells, which are stromal cells that support the proliferation and differentiation of $\mathrm{T}$-lineage cells, in the presence of 4-OHT. After $72 \mathrm{~h}$ of induction, cells were harvested, and mRNA expression was analyzed by qRT-PCR. Down-regulation of Ring $1 b$ and up-regulation of B-lineage genes such as Ebf1 and Pax 5 were seen (Fig. 1G). These data indicate that a subset of B-lineage-associated genes is directly repressed by PRC1 in T-cell pro- genitors. As shown in Supplemental Figure S3A, CD19 expression in CD4SP and CD8SP cells in the thymi of Cd4Cre-Ring $1 a^{-/-}$Ring $1 b^{\mathrm{fl} / \mathrm{fl}}$ mice was barely detectable, indicating that suppression of B-cell genes by Ring $1 a / b$ persists until the DP stage, whereas Ring $1 a / b$ is dispensable at later stages of T-cell development.

\section{Conversion of thymic DP cells from LckCre-Cdkn2a-/-

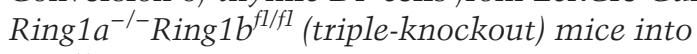 $B$ cells in vivo}

To determine the developmental plasticity of the affected T-cell progenitors, DP cells from the thymi of Lck tripleknockout and control mice were transferred to sublethally irradiated immunodeficient mice (Fig. 2A). Whereas DP cells from control mice gave rise to $\mathrm{CD} 4^{+} \mathrm{SP}$ and $\mathrm{CD}^{+} \mathrm{SP}$ mature $\mathrm{T}$ cells in the spleen, those from tripleknockout mice failed to generate $\mathrm{T}$ cells. Surprisingly, instead, the triple-knockout DP cells gave rise to $\mathrm{CD}_{1} 9^{+} \operatorname{IgM}^{+} \mathrm{B}$ cells in the spleens and BM of reconstituted mice (Fig. 2B,C). Similarly, upon transferring to immunodeficient mice, the CD19 ${ }^{-} \mathrm{DN} 3$ cells from Lck triple-
A

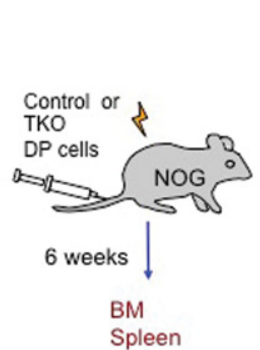

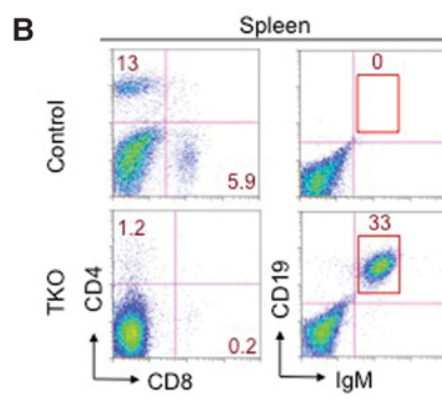

C
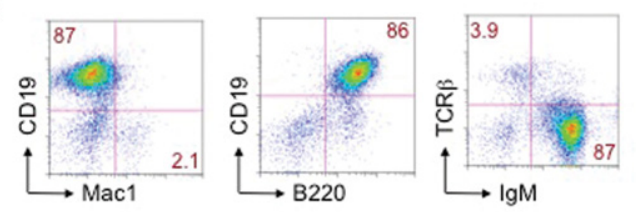

D

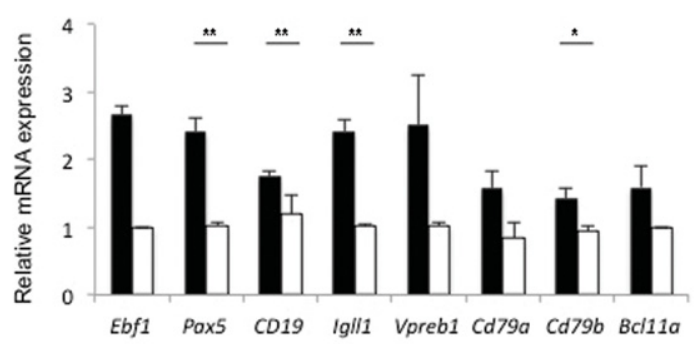

E

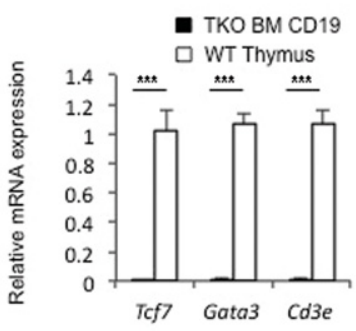

$\mathbf{F}$

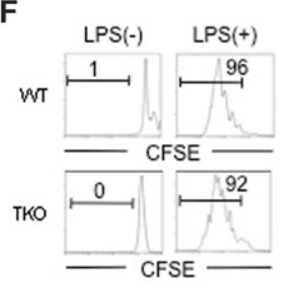

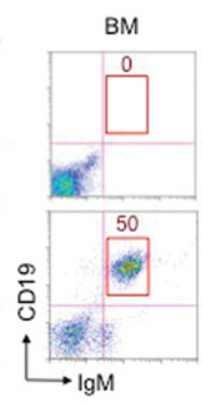

TKO BM CD19 WT BM CD 19
G

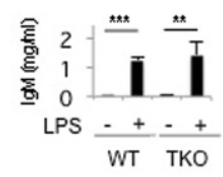

Figure 2. Conversion of thymic DP cells from

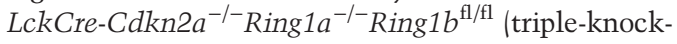
out [TKO]) mice into B cells in vivo. (A) Schematic representation for the developmental potential of DP cells from control or triple-knockout mice. (B) Flow cytometric analysis of cells in the spleens and BM of NOD/Shi-scid, IL2R $\gamma^{\text {null }}$ (NOG) mice transplanted with DP cells from control or triple-knockout mice. Expression of CD4 versus CD8 and CD19 versus IgM is shown. (C) Flow cytometric analysis of cells in the BM of NOG mice transplanted with DP cells of triple-knockout mice at $6 \mathrm{wk}$ after injection. Cells were analyzed for the expression of CD19 versus Mac 1, CD19 versus B220, and TCR $\beta$ versus IgM gated on CD45.2. $(D, E)$ qRT-PCR analysis of converted $\mathrm{B}$ cells purified from the BM for the expression of Blineage-associated $(D)$ or T-lineage-associated $(E)$ genes. $(F, G)$ In vitro stimulation of converted B cells for investigating proliferation and IgM secretion. Converted and wild-type splenic B cells were sorted and labeled with CFSE. The labeled cells were stimulated with LPS and IL-4 for $4 \mathrm{~d}$. Flow cytometric analysis $(F)$ and $\operatorname{IgM}$ secretion measured by ELISA $(G)$ of converted (triple-knockout) and wild-type B cells after stimulation are shown. Data are representative of at least three independent experiments. Mean \pm SD. $\left(^{*}\right) P<0.05 ;\left({ }^{* *}\right) P<0.01 ;\left({ }^{* * *}\right) P<0.001$, Student's $t$-test in $D, E$, and $G$. 
knockout mice also gave rise to $\mathrm{CD} 9^{+} \operatorname{IgM}^{+}$cells in the spleens and BM, whereas the DN3 cells and DP cells of Lck double-knockout mice failed to generate B-lineage cells (Supplemental Fig. S5). These data indicate that Lck triple-knockout $\mathrm{T}$-cell progenitors retain the potential to differentiate into B cells even after they reach the DP stage. Of note, we were not able to detect intermediate B-cell progenitors in the BM and spleen (Fig. 2B,C; Supplemental Fig. S5). Moreover, we failed to detect the transdifferentiation in vitro (data not shown), suggesting that the T-cell progenitors of Lck triple-knockout mice directly converted to $\mathrm{CD}_{19}{ }^{+} \mathrm{IgM}^{+}$cells.

The $\mathrm{CD} 19^{+} \mathrm{IgM}^{+}$cells derived from Lck triple-knockout DP cells were found to have a complete B-cell lineage identity because they express a set of B-cell lineage-associated genes at levels comparable with wild-type B cells, while T-cell lineage-associated genes such as Tcf7, Gata3, or Cd3e were almost undetectable (Fig. 2D,E). To determine the function of the converted $\mathrm{B}$ cells, the $\mathrm{CD}_{19}{ }^{+} \mathrm{IgM}^{+}$cells derived from Lck triple-knockout DP cells were labeled with CFSE and cultured with LPS and IL-4 for $4 \mathrm{~d}$. The B cells converted from LCK tripleknockout DP cells had a normal proliferative response and IgM secretion upon LPS and IL-4 stimulation, indicating that the converted B cells were functional (Fig. 2F,G).

\section{Rearrangements of immunoglobulin heavy chain (Igh) and Tcr $\beta$ chain genes in B cells derived from DP cells in the thymi of Lck triple-knockout mice}

Consistent with the surface expression of IgM, PCR analysis revealed $\mathrm{D}_{\mathrm{H}}-\mathrm{J}_{\mathrm{H}}$ and $\mathrm{V}_{\mathrm{H}}-\mathrm{DJ}_{\mathrm{H}}$ rearrangements on the Igh gene locus as well as $\mathrm{V} \kappa-\mathrm{J} \kappa$ and $\mathrm{V} \lambda-\mathrm{J} \lambda$ rearrangements of the immunoglobulin light chain $(\operatorname{Igl})$ locus in $\mathrm{CD} 19^{+} \operatorname{IgM}^{+}$ cells in the spleens of mice reconstituted with Lck tripleknockout DP cells, although they seemed to be oligoclonal. The converted B cells derived from Lck triple-knockout DP cells also carried V-DJ rearranged Tcr $\beta$ chain genes, confirming the T-cell origin of the cells (Fig. 3A).

To further confirm the conversion of T-lineage cells to $\mathrm{B}$ cells, we examined the T-cell- and B-cell-specific V-DJ rearrangements at the single-cell level by using the seminested PCR technique in individual B cells from the spleens of mice reconstituted with Lck triple-knockout DP cells (Nechanitzky et al. 2013). We detected both $\mathrm{V}_{\beta}$ and $\mathrm{V}_{\mathrm{H}}$ rearrangements in $14 \%-40 \%$ of the individual converted B cells (Fig. 3B; Table 1). These data demonstrate that the conversion event stably takes place at a certain frequency. Whereas one could argue that such oligoclonality is reminiscent of preleukemic clones, this is unlikely because the converted cells never developed into leukemia in recipient mice even several months after transplantation. Furthermore, the low rearrangement frequency of both $\mathrm{V}_{\beta}$ and $\mathrm{V}_{\mathrm{H}}$ loci was also shown previously in the case of the conversion of B cells to T-lineage cells of Pax5 knockout and Ebf1 knockout mice (Cobaleda et al. 2007; Nechanitzky et al. 2013).

\section{Association of Ring1B with the promoter regions of B-lineage-associated genes in thymocytes}

Previous studies have suggested that the PcG proteins regulate differentiation and maintenance of HSCs by controlling the expression of various target genes (Oguro et al. 2010; Aloia et al. 2013; Xie et al. 2014). Of note, the PRC1 component Bmi-1 is implicated in the repression of transcription factors essential for the generation of Blineage cells, such as Ebf1 and Pax5 (Oguro et al. 2010).
A

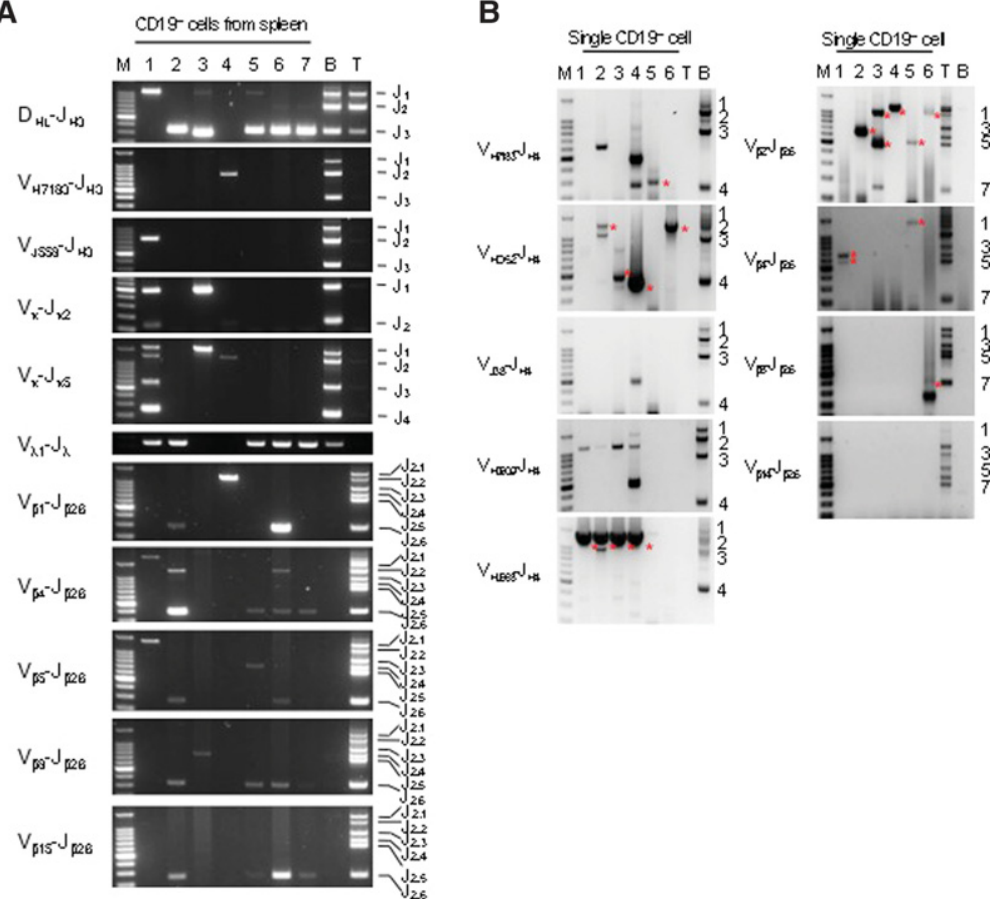

Figure 3. Rearrangements of $I g h$ and $\operatorname{Tcr} \beta$ chain genes in B cells derived from DP cells in the thymi of Lck triple-knockout mice. (A) Analysis of $I g h \mathrm{~V}$ (D)J, Igl $\mathrm{V} \kappa-\mathrm{J} \kappa$ and $\mathrm{V} \lambda-\mathrm{J} \lambda$, and $\operatorname{Tcr} \beta \mathrm{V}(\mathrm{D}) \mathrm{J}$ gene rearrangement in converted $\mathrm{B}$ cells derived from thymic DP cells of triple-knockout mice. BM CD19+ cells and DP thymocytes from normal B6 mice were used as controls. (B) Seminested single-cell PCR analysis to detect T-cell- and B-cell-specific rearrangements of $I g h$ and $T c r \beta$ loci in the individual converted B cells in the spleen. Asterisks indicate rearrangements detected. Data are shown from three independent experiments. 
Table 1. Quantification of $V(D) J$ rearrangement of Igh and Tcrb loci in individual B cells converted from DP cells in the thymi of Cdkn2a Ring1a/b triple-knockout mice

\begin{tabular}{lccc}
\hline & $\begin{array}{c}\mathrm{V}_{\mathrm{H}}(\mathrm{D}) \mathrm{J}_{\mathrm{H}} \\
\text { rearrangement }\end{array}$ & $\begin{array}{c}\mathrm{V}_{\beta}(\mathrm{D}) \mathrm{J}_{\beta} \\
\text { rearrangement }\end{array}$ & $\begin{array}{c}\text { Both } \\
\text { rearrangements }\end{array}$ \\
\hline Experiment 1 & $75.0 \%$ & $30.2 \%$ & $24.0 \%$ \\
Experiment 2 & $96.9 \%$ & $41.7 \%$ & $40.6 \%$ \\
Experiment 3 & $85.4 \%$ & $17.7 \%$ & $14.6 \%$ \\
\hline
\end{tabular}

Single-cell PCR analysis of Igh and Tcr $\beta$ gene rearrangement. The percentages of $\mathrm{V}_{\mathrm{H}}(\mathrm{D}) \mathrm{J}_{\mathrm{H}}$ and $\mathrm{V}_{\beta}(\mathrm{D}) \mathrm{J}_{\beta}$ rearrangements detected in individual $\mathrm{CD}^{-} \mathrm{CD}^{-} 9^{+} \mathrm{IgM}^{+}$cells in the spleens of mice transplanted with $\mathrm{CD}^{+} \mathrm{CD}^{+}$cells in the thymi of $C d k n 2 a$ Ring $1 a / b$ triple-knockout mice are shown. Data are shown as three independent experiments.

To examine Ring1B occupancy of B-lineage gene loci in normal T-lineage cells, chromatin immunoprecipitation (ChIP)-on-chip analysis of thymocytes was performed. The results revealed the binding of Ring $1 \mathrm{~B}$ to B-lineage-associated genes such as Pax5, Ebf1, Irf4, and Irf8 as well as H3K27me3, a hallmark of polycomb-repressive activity, in the same regions (Fig. 4A). The binding of Ring1B and H3K27me3 mark was not observed in the promoter regions of Gata3 or Bcl11b. We confirmed that binding of Ring1B and H3K27me3 marks was at the promoter regions of Pax5 and Ebf1 but not Bcl11b loci by ChIP analysis in normal $\mathrm{T}$ cells (Fig. 4B). To further confirm the Ring1B occupancy at the promoter regions of B-lineage loci in T cells, we performed ChIP-PCR analysis in DN3 and DP cells sorted from normal thymocytes. The substantial binding of Ring $1 \mathrm{~B}$ at the promoter regions of Pax5 and Ebf1 loci was observed in DN3 cells, whereas the binding of Ring1B was dramatically reduced in DP cells (Fig. 4C). These results indicate that Ring1A/B binds directly to B-lineage-associated gene loci to repress ectopic expression of these genes during T-cell development.

\section{Deletion of PAX5 restores T-cell development in Ring $1 A / B$-deficient mice}

To determine whether the main role of Ring1A/B is to repress Pax5 and the related B-lineage-associated gene programs, we investigated whether deletion of Pax5 would restore the development of $\mathrm{T}$ cells in the thymi of Ring1A/B-deficient mice. We bred LckCre-Ring1a $a^{-1-}$ Ring $1 b^{\mathrm{fl} / \mathrm{fl}}$ mice with $\operatorname{Pax} 5^{\mathrm{fl} / \mathrm{fl}}$ mice to generate T-cell-specific Ring1a/b Pax5 triple-knockout mice. Notably, $\mathrm{CD} 4^{+} \mathrm{CD} 8{ }^{+} \mathrm{DP}, \mathrm{CD} 4 \mathrm{SP}$, and CD8SP cells were normally generated in the thymi of PAX5 triple-knockout mice. The proportions of TCR $\beta^{+}$and TCR $\gamma \delta^{+}$cells were restored by the deletion of Pax5. The total number of thymocytes in PAX5 triple-knockout mice was also recovered to control levels (Fig. 5A,B; Supplemental Fig. S6). Similarly, The $\mathrm{CD}^{+} \mathrm{T}$ cells and $\mathrm{CD} 8^{+} \mathrm{T}$ cells were also normally generated in the spleens of PAX5 triple-knockout mice (Fig. 5C). These data indicated that deletion of Pax5 restored the differentiation potential of Ring $1 a / b$-deficient T-cell progenitors. Thus, PAX5 is one of the critical targets of PcG proteins during early T-cell development.

\section{Discussion}

In this study, we dissected the role of PcG proteins in the maintenance of T-cell fate by using the T-cell-specific Ring $1 a / b$-deficient mice. We demonstrated that the Pax5 locus is one of the main targets of PcG proteins to suppress the B-cell potential during early T-cell development. The maintenance of T-cell fate by PcG proteins continued throughout the thymocyte development. However, the deletion of Ring $1 a / b$ driven by the Cre transgene under the control of the Cd4 promoter did not show any

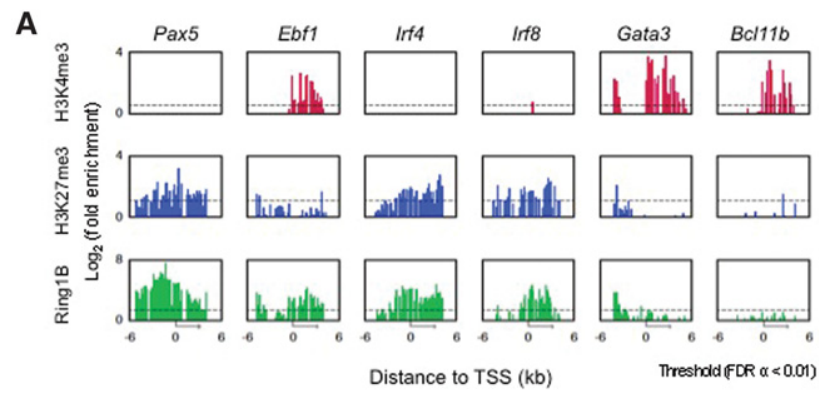

B
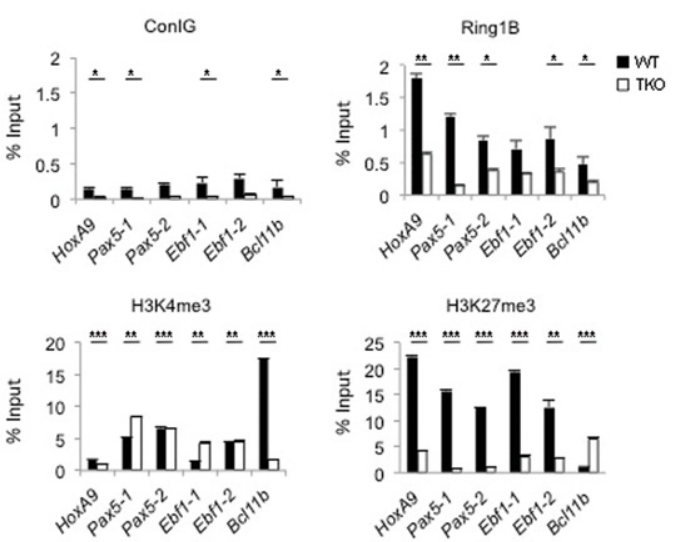

C

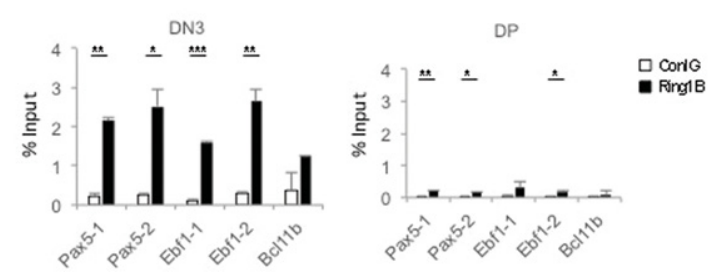

Figure 4. Association of Ring1B with the promoter regions of B-lineage-associated genes in thymocytes. (A) ChIP-on-chip analysis of total thymocytes from wild-type mice showing the H3K4me3, H3K27me3, and RING1B binding to the promoter regions (from $-6 \mathrm{~kb}$ to $+6 \mathrm{~kb}$ relative to the transcriptional start sites [TSS]) of the indicated B-lineage- or T-lineage-associated genes. (B) ChIP analysis showing binding of $\mathrm{H} 3 \mathrm{~K} 4 \mathrm{me} 3$, H3K27me3, and Ring1B at the promoter regions of Pax5, Ebf1, and Bcl11b and the PcG target Hoxa9 gene in T-lineage cells in the thymi of wild-type (WT) and Lck triple-knockout (TKO) mice. (C) ChIP analysis showing binding of Ring1B at the promoter regions of Pax5, Ebf1, and Bcl11b in DN3 and DP cells in the thymi of wild-type mice. Data are representative of at least three independent experiments in $B$ and $C$. Mean \pm SD. $\left.\left({ }^{*}\right) P<0.05 ;{ }^{* *}\right)$ $P<0.01 ;\left(^{* * *}\right) P<0.001$, Student's $t$-test. 
apparent defects of $\mathrm{T}$ cells in the spleen, indicating the critical role of PcG proteins in preventing the T-cell progenitors from choosing B-cell fate in the thymus.

The scenario of $\mathrm{T}$ - and B-cell lineage determination and maintenance is proposed as follows (Fig. 6). At the level of uncommitted progenitors, PcG proteins repress expression of critical B-cell lineage transcription factors such as PAX5. During the B-cell lineage determination process, Pax5 is up-regulated by being released from PcG-mediated repression. On the other hand, even after the T-lineage determination step, which is initiated at the DN1 stage by Notch signaling and completed during the DN2 stage by $B c 111 b$ up-regulation (Ikawa et al. 2010; Li et al. 2010a, b), PcG-mediated repression of Pax5 is indispensable for maintaining the T-cell lineage. When this repression is abolished, Pax5 is up-regulated in T-cell progenitors, and such cells can eventually be converted into B cells. Since constitutive activation of Pax 5 under control of the Ikaros locus was not able to induce conversion of $\mathrm{T}$ cells to $\mathrm{B}$ cells (Souabni et al. 2002), sustained epigenetic suppression of B-lineage-associated genes other than Pax5, such

A
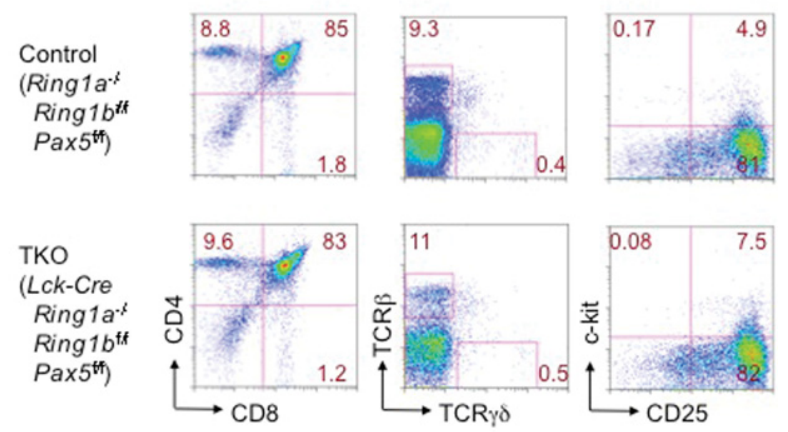

B

C
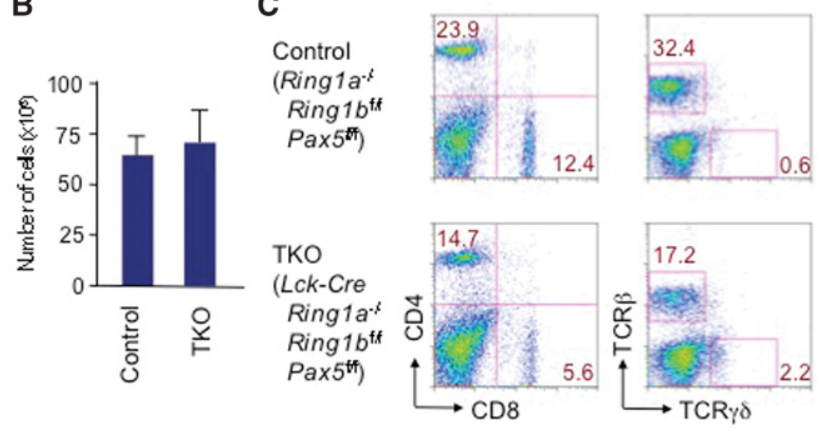

Figure 5. Deletion of Pax 5 restores T-cell development in the thymi and spleens of Ring1A/B double-knockout mice. $(A)$ Flow cytometric analysis of cells from the thymi of LckCre(-) (control) or LckCrel+) (triple-knockout [TKO]) Ring1A ${ }^{-/-}$ Ring $1 \mathrm{~B}^{\mathrm{fl} / \mathrm{fl}} \mathrm{Pax} 5^{\mathrm{fl} / \mathrm{fl}}$ mice. Thymocytes gated on $\mathrm{Lin}^{-}$cells were analyzed for the expression of CD4 versus CD8, TCR $\beta$ versus TCR $\gamma \delta$, and c-kit versus CD25. (B) The number of thymocytes in control or triple-knockout mice. $(C)$ Flow cytometric analysis of cells from the spleens of LckCre(-) (control) or LckCre(+) (triple-knockout) Ring $1 \mathrm{~A}^{-/-} \operatorname{Ring} 1 \mathrm{~B}^{\mathrm{fl} / \mathrm{fl}} \mathrm{Pax} 5^{\mathrm{fl} / \mathrm{fl}}$ mice. Splenocytes were analyzed for the expression of CD4 versus CD8 and TCR $\beta$ versus TCR $\gamma \delta$. Data are representative of at least three independent experiments in $A-C$. Mean $\pm \mathrm{SD}$ in $B$. as $E b f 1$ and $B \operatorname{lnk}$, is also required for the normal T-lineage program. The transcription factor Bcl11b is shown to be essential for T-cell versus NK cell fate determination (Ikawa et al. 2010; Li et al. 2010a,b). Of note, the expression of $B c 111 b$ did not change in Ring $1 a / b$ knockout T-cell progenitors (Fig. $1 \mathrm{~F}$ ), suggesting that the PcG proteins do not directly regulate the expression of $B c 111 b$ in the maintenance of T-cell fate. This may explain why Ring1a/b-deficient $\mathrm{T}$-cell progenitors did not take the NK cell fate. During this transition phase, the myeloid lineage program is not activated, probably because both Notch signal and PAX5 activity suppress the myeloid program (Nutt et al. 1999; Busslinger 2004; Rothenberg et al. 2008).

Previous studies indicated that Ring1B is critical for the maintenance and differentiation of HSCs. Conditional inactivation of Ring $1 b$ in hematopoietic cells promotes myeloid lineage development at the expense of B-cell differentiation (Cales et al. 2008). The additional deletion of the $p 16^{\text {Ink4a }}$ locus rescued the defective proliferation of B-cell progenitors in the BM of Ring1b-deficient mice, suggesting an important role of Ring $1 b$ in repressing the expression of $p 16^{\text {Ink4a }}$ for the control of proliferation and differentiation of the hematopoietic progenitors. In the present study, we observed severe reduction of $\mathrm{T}$ cells in the thymi of LckCre-Ring1a/b double-knockout mice. However, the $\mathrm{T}$-cell differentiation was not recovered by the additional inactivation of $C d k n 2 a$, which encodes $p 16^{\text {Ink4a }}$ and $p 19^{\text {arf }}$. Moreover, the T-cell progenitors of Ring1a/b Cdkn2a triple-knockout mice reprogrammed to B-lineage cells in vivo. This might reflect the functional redundancy between Ring1A and Ring1B, although it is reported that the inactivation of Ring1a, a paralog of Ring1b in mice, results in no overt phenotypes (del Mar Lorente et al. 2000). This could also be due to the functional differences of Ring1B among the cell types and the differentiation stages of the cells. Indeed, the Ring $1 b$ deficent myeloid cells exhibit higher proliferative potential than normal myeloid cells (Cales et al. 2008). Of note, proteomic analysis has recently identified the functionally distinct PRC1 complexes (Gao et al. 2012). All PRC1 complexes contain Ring1A/B but can be classified into six groups based on which PcG RING fingers (PCGFs) are involved. Biochemical and genomic analysis revealed the functional difference among the PRC1 complexes. PCGFs may play a key role in controlling the cell fate decision in differentiating cells. Further analysis will be needed to determine the exact role of Ring $1 a$ and Ring $1 b$ among PRC1 complexes in regulating the determination of cell fates.

Our present results provide the first example that the inactivation of a single epigenetic machinery results in a drastic cell fate conversion, providing new insight into the mechanisms of lineage determination. We propose that the determined status is very asymmetric between $\mathrm{T}$ lineage and $\mathrm{B}$ lineage with regard to its dependency on transcriptional networks versus epigenetic regulation. The B-cell lineage is primarily maintained by B-lineage transcription factors, while maintenance of the $\mathrm{T}$ lineage requires epigenetic suppression of B-lineage transcription 


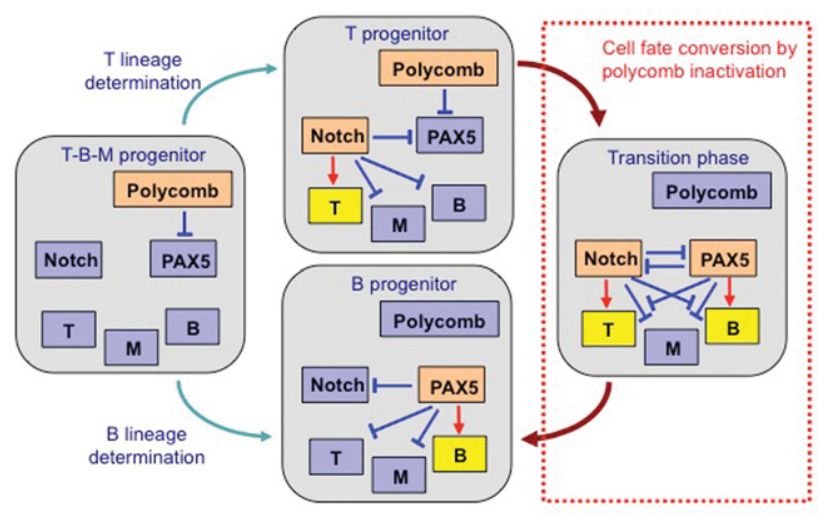

Figure 6. Model of T or B lymphoid lineage commitment regulated by PcG proteins. The predicted function of PcG proteins during $\mathrm{T}$ - and $\mathrm{B}$-cell development from $\mathrm{T} / \mathrm{B} / \mathrm{M}$ multipotent progenitors is shown. The orange and blue boxes reflect the activity of each genetic program. For example, orange represents the activated gene program, whereas blue represents the repressed gene program in each progenitor state. Yellow represents the activated cell status in T-cell progenitors, B-cell progenitors, and a transition phase.

factors. Based on such findings, it appears that the B-cell lineage and not the T-cell lineage is the default pathway in lymphocyte development. Thus, one can conceive that the T-cell lineage was established during evolution by suppressing a pre-existing B-cell program. Alternatively, it can also be speculated that the B-cell lineage was introduced rather later during evolution by recruiting very strong transcription factors and that the T-cell lineage had to suppress them to protect its own developmental program. Although so far it is difficult to tell which is the case, the present findings may provide some clue as to how cell lineages were established during evolution.

\section{Materials and methods}

Mice

C57BL/6 (B6) mice were purchased from CLEA Japan, Inc. LckCre-Cdkn2a $a^{-/-}$Ring $1 a^{-/-}$Ring $1 b^{\mathrm{fl} / \mathrm{fl}}$, LckCre-Cdkn2a-lRing $1 a^{-/-}$Ring $1 b^{\mathrm{fl} / \mathrm{fl}}$ Pax $5^{\mathrm{fl} / \mathrm{fl}}, \quad$ Ert2Cre-Cdkn2a $a^{-/-}$Ring $1 a^{-/-}$ Ring $1 b^{\mathrm{fl} / \mathrm{fl}}$, Cd4Cre-Cdkn2 $a^{-/-}$Ring $1 a^{-/-}$Ring $1 b^{\mathrm{fl} / \mathrm{fl}}$, and Ring1BYFP mice were generated and maintained in our animal facility. Mice were backcrossed to B6 mice at least six times. NOD/Shiscid, IL2R $\gamma^{\text {null }}$ (NOG) mice were purchased from the Central Institute for Experimental Animals. Six-week-old to 8-wk-old female mice were used for the transfer experiments.

\section{Antibodies}

The following antibodies were purchased from BD Biosciences: fluorescein isothiocyanate (FITC)-conjugated erythroid lineage cells (TER119; 561032), MAC1 (553310), GR1 (553127), CD11C (557400), B220 (553088), THY1.2 (553004), CD8A (553031), CD4 (553651), NK1.1 (553164), CD3ع (553062), CD19 (553785), TCR $\gamma \delta$ (553177), phycoerythrin (PE)-conjugated SCA-1 (553336), CD4 (553653), CD19 (553786), GR-1 (553128), NK1.1 (553165), TCR $\beta$ (553172), allophycocyanin (APC)-conjugated LY5.1
(558701), LY5.2 (558702), C-KIT (553556), and CD19 (550992). FITC-IGM (11-5790-81) was purchased from eBioscience.

\section{Growth factors}

Recombinant murine (rm) SCF, IL-7, and Flt3-ligand (L) were purchased from R\&D.

\section{Isolation of thymic $\mathrm{Lin}^{-}$cells}

Single-cell suspensions of thymocytes were prepared from LckCre-Cdkn2 $a^{-/-}$Ring $1 a^{-/-}$Ring $1 b^{\mathrm{fl} / \mathrm{fl}}$ and control mice. Cells were then incubated with $\mathrm{mAbs}$ specific for Lin markers (TER119, Mac-1, Gr-1, B220, CD3, CD4, and CD8) for $20 \mathrm{~min}$ on ice. $\mathrm{Lin}^{+}$cells were depleted with Dynabeads sheep anti-rat IgG (Invitrogen) according to the manufacturer's protocol. The Lin $^{-}$cells were used for subsequent experiments.

\section{In vitro deletion of Ring $1 b$ in sorted DN3 cells}

Single-cell suspensions of the thymi from Ert2Cre-Cdkn2a-/Ring $1 a^{-/-}$Ring $1 b^{\mathrm{fl} / \mathrm{fl}}$ mice were prepared. Lin ${ }^{-}$cells were purified using Dynabeads sheep anti-rat IgG as described above. DN3 cells were sorted as $\mathrm{Lin}^{-} \mathrm{ckit}^{-} \mathrm{CD} 25^{+}$cells after staining with FITC-Lin, PE-CD25, and APC-ckit antibodies. The purified DN3 cells were subsequently incubated on TSt-4/DLL1 cells for $72 \mathrm{~h}$ in RPMI 1640 medium (GIBCO-BRL) supplemented with 10\% FBS, $2 \mathrm{mM}$ L-glutamine, $1 \mathrm{mM}$ sodium pyruvate, $2 \mathrm{mg} / \mathrm{mL}$ sodium bicarbonate, $0.1 \mathrm{mM}$ nonessential amino acid solution (GIBCO$\mathrm{BRL}), 5 \times 10^{-5} \mathrm{M} 2-\mathrm{ME}, 100 \mathrm{mg} / \mathrm{mL}$ streptomycin, $100 \mathrm{U} / \mathrm{mL}$ penicillin, $1 \mu \mathrm{M}$ 4-OHT, $10 \mathrm{ng} / \mathrm{mL}$ SCF, $10 \mathrm{ng} / \mathrm{mL}$ IL-7, and $10 \mathrm{ng} / \mathrm{mL}$ Flt3-L. The cultured cells were stained with anti-CD45 antibody, and $\mathrm{CD} 45^{+}$cells were sorted. RNA was extracted from the sorted cells, and the RNA levels were measured by qRT-PCR.

\section{In vitro B-cell culture}

$\mathrm{CD} 19^{+} \mathrm{B}$ cells were sorted from the splenocytes of wild-type and NOG mice transplanted with DP cells from LckCre-Cdkn2a-lRing $1 a^{-/-}$Ring $1 b^{\mathrm{fl} / \mathrm{fl}}$ mice. Collected cells were labeled with $5 \mu \mathrm{M}$ CFSE (Nacalai Tesque) for $20 \mathrm{~min}$ at $37^{\circ} \mathrm{C}$. Labeled cells were cultured in RPMI 1640 supplemented with 10\% FBS, $2 \mathrm{mM}$ L-glutamine, $1 \mathrm{mM}$ sodium pyruvate, $2 \mathrm{mg} / \mathrm{mL}$ sodium bicarbonate, $0.1 \mathrm{mM}$ nonessential amino acid solution (GIBCO$\mathrm{BRL}), 5 \times 10^{-5} \mathrm{M} 2-\mathrm{ME}, 100 \mathrm{mg} / \mathrm{mL}$ streptomycin, and 100 $\mathrm{U} / \mathrm{mL}$ penicillin. LPS (Sigma-Aldrich) and IL-4 (R\&D Systems) were also added as indicated. After $96 \mathrm{~h}$ of culture, cell division was measured by FACS, and IgM secretion was measured by ELISA as described previously (Kometani et al. 2011).

\section{ELISA}

Ninety-six-well flat-bottomed plates were coated with $2 \mu \mathrm{g} / \mathrm{mL}$ anti-mouse IgM for $1 \mathrm{~h}$ at room temperature followed by blocking with $0.5 \%$ BSA in PBS for $1 \mathrm{~h}$ at room temperature. Serially diluted samples were incubated for $1 \mathrm{~h}$ at room temperature. After washing with PBS/0.5\% Tween-20, horseradish peroxidase-conjugated anti-mouse IgM antibodies (SouthernBiotech) were used as the substrate, and absorbance at $450 \mathrm{~nm}$ was measured using a microplate reader (Bio-Rad Laboratories). 


\section{Adoptive transfer of DN3 or DP cells}

DN3 or DP cells $\left(1 \times 10^{6}\right.$ cells) from $L c k C r e-C d k n 2 a^{-/}$Ring $1 a^{-/-}$ Ring $1 b^{\mathrm{fl} / \mathrm{fl}}$ mice were intravenously injected into the tail veins of sublethally irradiated (240 rad) NOG mice. Mice were analyzed 4-6 wk after reconstitution for donor chimerism in the BM and spleen.

\section{PCR analysis of Igh and Tcr $\beta$ gene rearrangement}

The analysis of $I g h$ and $\operatorname{Tcr} \beta$ gene rearrangement was performed as described previously (Ikawa et al. 2004). In brief, genomic DNA was prepared from B cells derived from the spleens and $\mathrm{BM}$ in mice transplanted with thymic DN3 or DP cells from LckCre-Cdkn2 $a^{-/-}$Ring $1 a^{-/-}$Ring $1 b^{\mathrm{fl} / \mathrm{fl}}$ and control mice using the DNeasy tissue kit (Qiagen). The reaction volume was $20 \mu \mathrm{L}$, containing $2 \mu \mathrm{L}$ of genomic DNA (approximately equivalent to $10^{4}$ cells), $2 \mu \mathrm{L}$ of $10 \times$ PCR buffer, $0.16 \mu \mathrm{L}$ of $25 \mathrm{mM}$ dNTP, 4 pmol of each primer, and $0.6 \mathrm{U}$ of Taq polymerase (GE healthcare). The PCR reactions were performed as follows: $5 \mathrm{~min}$ at $94^{\circ} \mathrm{C}$ followed by 35 cycles of $1 \mathrm{~min}$ at $94^{\circ} \mathrm{C}, 1 \mathrm{~min}$ at $60^{\circ} \mathrm{C}, 2 \mathrm{~min}$ at $72^{\circ} \mathrm{C}$, and finally $10 \mathrm{~min}$ at $72^{\circ} \mathrm{C}$. Amplified DNA products were analyzed on an agarose gel followed by ethidium bromide staining.

\section{Single-cell-based PCR analysis of Igh and Tcr $\beta$ gene rearrangement}

The analysis was performed as described previously (Nechanitzky et al. 2013). Briefly, single converted B cells in the spleens of NOG mice derived from DP cells in the thymi of Lck tripleknockout mice were directly sorted into one well of a 96-well plate containing $20 \mu \mathrm{L}$ of PCR buffer (Takara) supplemented with $250 \mu \mathrm{g} / \mathrm{mL}$ proteinase K. Single cells were digested by incubation for $60 \mathrm{~min}$ at $56^{\circ} \mathrm{C}$ followed by inactivation of proteinase $\mathrm{K}$ for $15 \mathrm{~min}$ at $95^{\circ} \mathrm{C}$. The first round of PCR was done by the addition of $30 \mu \mathrm{L}$ of PCR mix containing dNTPs, PCR buffer, and rTaq (all from Takara) as well as primers for detecting $\mathrm{V}(\mathrm{D}) \mathrm{J}$ recombination of IgH and TCR $\beta$ gene loci (Supplemental Table S3) . An aliquot of $1 \mu \mathrm{L}$ of the product of the first round of PCR and the nested primers (JH4 and J 32.7 ) in combination with one of the $\mathrm{V}_{\mathrm{H}}$ or $\mathrm{V}_{\beta}$ primers was used for the second round of PCR. Amplified DNA products were analyzed on an agarose gel followed by ethidium bromide staining.

\section{$R N A$ extraction and $q R T-P C R$}

Total RNA was isolated using an RNeasy kit (Qiagen). cDNA synthesis was performed using a SuperScript VILO cDNA synthesis kit (Invitrogen) following the manufacturer's protocol. Realtime PCR was performed using SYBR Premix EX Taq (Takara) and analyzed by StepOnePlus (Applied Biosystems). The reactions were performed in duplicate for $10 \mathrm{sec}$ at $95^{\circ} \mathrm{C}$ followed by 40 cycles of $5 \mathrm{sec}$ at $95^{\circ} \mathrm{C}$ and $30 \mathrm{sec}$ at $55^{\circ} \mathrm{C}$. The primer sequences used are in Supplemental Table S1.

\section{Microarray analysis}

RNA extraction was performed as described above. The expression profiles were analyzed using a Quant-iT RiboGreen RNA assay kit (Invitrogen). The quality of the RNA was analyzed using an Agilent 2100 Bioanalyzer (Agilent). The fluorescence intensities were detected using the Scan-Array Lite scanner (PerkinElmer). The PMT levels were adjusted to achieve $0.1 \%-0.5 \%$ pixel saturation. Each TIFF image was analyzed using Gene Pix
Pro version 6.0 software (Molecular Devoices). The data were filtered to remove low-confidence measurements and globally normalized per array such that the median of the signal intensity was adjusted to 50 after normalization (accession no. GSE53650).

\section{ChIP analysis}

ChIP assays were performed as described (Ikawa et al. 2006; Endoh et al. 2008). Immunoprecipitated and input DNA were quantified by real-time PCR with the primers in Supplemental Table S2.

\section{ChIP-on-chip analysis}

ChIP-on-chip analysis was carried out using the mouse promoter ChIP-on-chip microarray set (Agilent Technologies, G4490A) as described previously (Endoh et al. 2008). Thymocytes of normal B6 mice were subjected to ChIP assay using anti-H3K4me3, anti-H3K27me3, and anti-Ring1B antibodies. Purified immunoprecipitated and input DNA were subjected to blunt ligation with linker oligo DNA, linker-mediated PCR (LM-PCR), labeling, hybridization, and washing following the Agilent mammalian ChIP-on-chip protocol. Scanned images were quantified with Agilent Feature Extraction software under standard conditions.

Assignment of regions bound by H3K4me3, H3K27me3, and Ring1B around transcription start sites was carried out using direct sequence alignment on the mouse genome database (NCBI version 36). The location of bound regions of each protein was compared with a set of transcripts derived from the Mouse Genome Informatics database. We assigned bound regions that were within $-6 \mathrm{~kb}$ to $+6 \mathrm{~kb}$ of the transcription start site. Alignments on the mouse genome and transcription start sites of genes were retrieved from Ensembl (http://www.ensembl.org).

The measured intensity ratios (immunoprecipitate/input: fold enrichment) were calculated, and the maximum value of the ratios in each promoter region $(-6 \mathrm{~kb}$ to $+6 \mathrm{~kb}$ around the transcriptional start site) of a gene was used to represent the fold enrichment of the gene. Fold enrichment was calculated only for probes whose signals from both immunoprecipitated and input DNAs were significant $\left(P<10^{-3}\right)$ (accession no. GSE53650).

\section{Acknowledgements}

We are grateful to M. Yamashita, D. Yamada, J. Sharif, K. Moro, S. Koyasu, R. Nechanitzky, and R. Grosschedl for sharing the protocols, supporting this project, and helpful comments; P. Burrows for critical reading of the manuscript; and A. Shibano-Satoh, M. Ohno, and M. Nakano-Ikegaya for technical assistance. This work was supported in part by grants from the Japan Society for the Promotion of Science (24689042 to T.I.), the Japan Science and Technology Agency (T.I.), RIKEN Center for Integrative Medical Sciences (IMS) Young Chief Investigator program (T.I.), and the Kanae Foundation for the Promotion of Medical Science (T.I.). T.I., H. Koseki, and H. Kawamoto designed and performed experiments with the assistance of K.M., T.A.E., M.E., K.I., Y.K., R.N., K.K., J.T., Y.A., T.K., and M.V. Y.K. gave insightful comments on designing the experiments and writing the paper. T.I. and H. Kawamoto wrote the paper.

\section{References}

Aloia L, Di Stefano B, Di Croce L. 2013. Polycomb complexes in stem cells and embryonic development. Development 140: 2525-2534. 
Bell JJ, Bhandoola A. 2008. The earliest thymic progenitors for T cells possess myeloid lineage potential. Nature 452: 764-767.

Busslinger M. 2004. Transcriptional control of early B cell development. Annu Rev Immunol 22: 55-79.

Cales C, Roman-Trufero M, Pavon L, Serrano I, Melgar T, Endoh M, Perez C, Koseki H, Vidal M. 2008. Inactivation of the polycomb group protein Ring1B unveils an antiproliferative role in hematopoietic cell expansion and cooperation with tumorigenesis associated with Ink4a deletion. Mol Cell Biol 28: 1018-1028.

Challen GA, Sun D, Mayle A, Jeong M, Luo M, Rodriguez B, Mallaney C, Celik H, Yang L, Xia Z, et al. 2014. Dnmt3a and Dnmt3b have overlapping and distinct functions in hematopoietic stem cells. Cell Stem Cell 15: 350-364.

Cobaleda C, Jochum W, Busslinger M. 2007. Conversion of mature B cells into $\mathrm{T}$ cells by dedifferentiation to uncommitted progenitors. Nature 449: 473-477.

del Mar Lorente M, Marcos-Gutierrez C, Perez C, Schoorlemmer J, Ramirez A, Magin T, Vidal M. 2000. Loss- and gain-of-function mutations show a polycomb group function for Ring $1 \mathrm{~A}$ in mice. Development 127: 5093-5100.

Endoh M, Endo TA, Endoh T, Fujimura Y, Ohara O, Toyoda T, Otte AP, Okano M, Brockdorff N, Vidal M, et al. 2008. Polycomb group proteins Ring1A/B are functionally linked to the core transcriptional regulatory circuitry to maintain ES cell identity. Development 135: 1513-1524.

Gao Z, Zhang J, Bonasio R, Strino F, Sawai A, Parisi F, Kluger Y, Reinberg D. 2012. PCGF homologs, CBX proteins, and RYBP define functionally distinct PRC1 family complexes. Mol Cell 45: 344-356.

Ieda M, Fu JD, Delgado-Olguin P, Vedantham V, Hayashi Y, Bruneau BG, Srivastava D. 2010. Direct reprogramming of fibroblasts into functional cardiomyocytes by defined factors. Cell 142: 375-386.

Ikawa T, Kawamoto H, Wright LY, Murre C. 2004. Long-term cultured E2A-deficient hematopoietic progenitor cells are pluripotent. Immunity 20: 349-360.

Ikawa T, Kawamoto H, Goldrath AW, Murre C. 2006. E proteins and Notch signaling cooperate to promote $\mathrm{T}$ cell lineage specification and commitment. J Exp Med 203: 1329-1342.

Ikawa T, Hirose S, Masuda K, Kakugawa K, Satoh R, ShibanoSatoh A, Kominami R, Katsura Y, Kawamoto H. 2010. An essential developmental checkpoint for production of the T cell lineage. Science 329: 93-96.

Isono K, Endo TA, Ku M, Yamada D, Suzuki R, Sharif J, Ishikura T, Toyoda T, Bernstein BE, Koseki H. 2013. SAM domain polymerization links subnuclear clustering of PRC1 to gene silencing. Dev Cell 26: 565-577.

Iwama A, Oguro H, Negishi M, Kato Y, Morita Y, Tsukui H, Ema H, Kamijo T, Katoh-Fukui Y, Koseki H, et al. 2004. Enhanced self-renewal of hematopoietic stem cells mediated by the polycomb gene product Bmi-1. Immunity 21: 843-851.

Kometani K, Yamada T, Sasaki Y, Yokosuka T, Saito T, Rajewsky K, Ishiai M, Hikida M, Kurosaki T. 2011. CIN85 drives B cell responses by linking BCR signals to the canonical NF- $\kappa B$ pathway. J Exp Med 208: 1447-1457.

Laiosa CV, Stadtfeld M, Xie H, de Andres-Aguayo L, Graf T. 2006. Reprogramming of committed $\mathrm{T}$ cell progenitors to macrophages and dendritic cells by C/EBPa and PU.1 transcription factors. Immunity 25: 731-744.

Li L, Leid M, Rothenberg EV. 2010a. An early T cell lineage commitment checkpoint dependent on the transcription factor Bcl11b. Science 329: 89-93.

Li P, Burke S, Wang J, Chen X, Ortiz M, Lee SC, Lu D, Campos L, Goulding D, Ng BL, et al. 2010b. Reprogramming of T cells to natural killer-like cells upon Bcl11b deletion. Science 329: 85-89.

Lu M, Kawamoto H, Katsube Y, Ikawa T, Katsura Y. 2002. The common myelolymphoid progenitor: a key intermediate stage in hemopoiesis generating $\mathrm{T}$ and $\mathrm{B}$ cells. I Immunol 169: 3519-3525.

Mandel EM, Grosschedl R. 2010. Transcription control of early B cell differentiation. Curr Opin Immunol 22: 161-167.

Masuda K, Kakugawa K, Nakayama T, Minato N, Katsura Y, Kawamoto H. 2007. T cell lineage determination precedes the initiation of TCR $\beta$ gene rearrangement. I Immunol 179: 3699-3706.

Miyazaki M, Kawamoto H, Kato Y, Itoi M, Miyazaki K, Masuda $\mathrm{K}$, Tashiro S, Ishihara H, Igarashi K, Amagai T, et al. 2005. Polycomb group gene mel-18 regulates early $\mathrm{T}$ progenitor expansion by maintaining the expression of Hes-1, a target of the Notch pathway. J Immunol 174: 2507-2516.

Miyazaki M, Miyazaki K, Itoi M, Katoh Y, Guo Y, Kanno R, Katoh-Fukui Y, Honda H, Amagai T, van Lohuizen M, et al. 2008. Thymocyte proliferation induced by pre- $\mathrm{T}$ cell receptor signaling is maintained through polycomb gene product Bmi1-mediated Cdkn2a repression. Immunity 28: 231-245.

Nechanitzky R, Akbas D, Scherer S, Gyory I, Hoyler T, Ramamoorthy S, Diefenbach A, Grosschedl R. 2013. Transcription factor EBF1 is essential for the maintenance of B cell identity and prevention of alternative fates in committed cells. Nat Immunol 14: 867-875.

Nutt SL, Heavey B, Rolink AG, Busslinger M. 1999. Commitment to the B-lymphoid lineage depends on the transcription factor Pax5. Nature 401: 556-562.

Oguro H, Yuan J, Ichikawa H, Ikawa T, Yamazaki S, Kawamoto H, Nakauchi H, Iwama A. 2010. Poised lineage specification in multipotential hematopoietic stem and progenitor cells by the polycomb protein Bmil. Cell Stem Cell 6: 279-286.

Rothenberg EV, Moore JE, Yui MA. 2008. Launching the T-celllineage developmental programme. Nat Rev Immunol 8: 9-21.

Satoh Y, Yokota T, Sudo T, Kondo M, Lai A, Kincade PW, Kouro T, Iida R, Kokame K, Miyata T, et al. 2013. The Satb1 protein directs hematopoietic stem cell differentiation toward lymphoid lineages. Immunity 38: 1105-1115.

Souabni A, Cobaleda C, Schebesta M, Busslinger M. 2002. Pax5 promotes B lymphopoiesis and blocks $\mathrm{T}$ cell development by repressing Notch1. Immunity 17: 781-793.

Sparmann A, van Lohuizen M. 2006. Polycomb silencers control cell fate, development and cancer. Nat Rev Cancer 6: 846-856.

Szabo E, Rampalli S, Risueno RM, Schnerch A, Mitchell R, Fiebig-Comyn A, Levadoux-Martin M, Bhatia M. 2010. Direct conversion of human fibroblasts to multilineage blood progenitors. Nature 468: 521-526.

Takahashi K, Yamanaka S. 2006. Induction of pluripotent stem cells from mouse embryonic and adult fibroblast cultures by defined factors. Cell 126: 663-676.

Trowbridge JJ, Snow JW, Kim J, Orkin SH. 2009. DNA methyltransferase 1 is essential for and uniquely regulates hematopoietic stem and progenitor cells. Cell Stem Cell 5: 442-449.

van der Lugt NM, Domen J, Linders K, van Roon M, RobanusMaandag E, te Riele H, van der Valk M, Deschamps J, Sofroniew M, van Lohuizen M, et al. 1994. Posterior transformation, neurological abnormalities, and severe hematopoietic defects in mice with a targeted deletion of the bmi-1 proto-oncogene. Genes Dev 8: 757-769.

Voncken JW, Roelen BA, Roefs M, de Vries S, Verhoeven E, Marino S, Deschamps J, van Lohuizen M. 2003. Rnf2 (Ring1b) 
deficiency causes gastrulation arrest and cell cycle inhibition. Proc Natl Acad Sci 100: 2468-2473.

Wada H, Masuda K, Satoh R, Kakugawa K, Ikawa T, Katsura Y, Kawamoto H. 2008. Adult T-cell progenitors retain myeloid potential. Nature 452: 768-772.

Will B, Vogler TO, Bartholdy B, Garrett-Bakelman F, Mayer J, Barreyro L, Pandolfi A, Todorova TI, Okoye-Okafor UC, Stanley $\mathrm{RF}$, et al. 2013. Satb1 regulates the self-renewal of hematopoi- etic stem cells by promoting quiescence and repressing differentiation commitment. Nat Immunol 14: 437-445.

Xie H, Ye M, Feng R, Graf T. 2004. Stepwise reprogramming of B cells into macrophages. Cell 117: 663-676.

Xie H, Xu J, Hsu JH, Nguyen M, Fujiwara Y, Peng C, Orkin SH. 2014. Polycomb repressive complex 2 regulates normal hematopoietic stem cell function in a developmental-stage-specific manner. Cell Stem Cell 14: 68-80. 


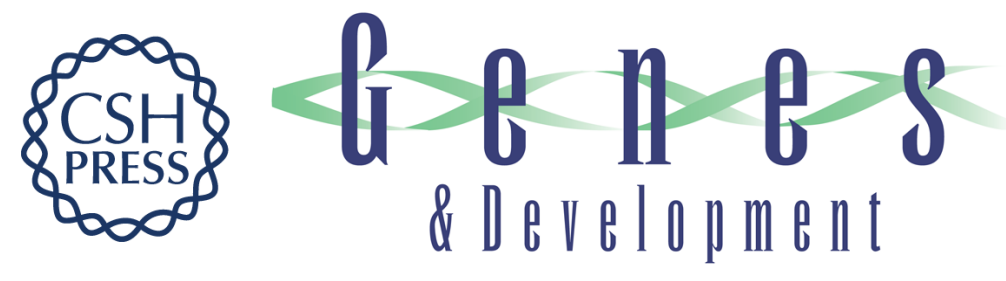

\section{Conversion of $T$ cells to $B$ cells by inactivation of polycomb-mediated epigenetic suppression of the B-lineage program}

Tomokatsu Ikawa, Kyoko Masuda, Takaho A. Endo, et al.

Genes Dev. 2016, 30: originally published online December 2, 2016

Access the most recent version at doi:10.1101/gad.290593.116

\section{Supplemental http://genesdev.cshlp.org/content/suppl/2016/12/02/gad.290593.116.DC1 Material}

References This article cites 40 articles, 14 of which can be accessed free at: http://genesdev.cshlp.org/content/30/22/2475.full.html\#ref-list-1

Creative This article is distributed exclusively by Cold Spring Harbor Laboratory Press for the first Commons six months after the full-issue publication date (see

License http://genesdev.cshlp.org/site/misc/terms.xhtml). After six months, it is available under a Creative Commons License (Attribution-NonCommercial 4.0 International), as described at http://creativecommons.org/licenses/by-nc/4.0/.

Email Alerting Receive free email alerts when new articles cite this article - sign up in the box at the top Service right corner of the article or click here.

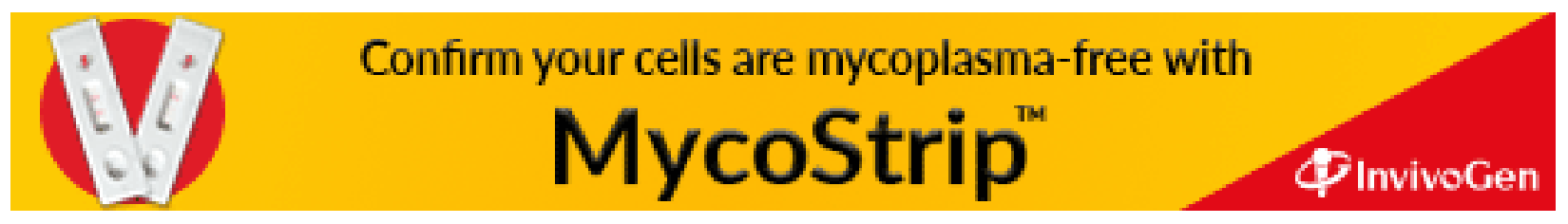

